Иркутский государственный аграрный университет ил. А. А. Ежевского, пос. Молодежный, Российская Федерация

С. И. Винокуров

Иркутский государственный аграрный университет ил. А. А. Ежевского, пос. Молодежный, Российская Федераиия

\title{
КОМБИНАЦИЯ СТРАТЕГИЧЕСКОГО И СТЕЙКХОЛДЕРСКОГО ПОДХОДОВ К РАЗВИТИЮ ИНТЕГРИРОВАНО-ДИВЕРСИФИЦИРОВАННОЙ КОМПАНИИ ПИЩЕВОЙ ПРОМЫШЛЕННОСТИ
}

\begin{abstract}
АНнОтАЦия. В статье описаны проблемы развития компаний пищевой промышленности. Обосновано применение комбинации стратегического и стейкхолдерского подходов к развитию интегрировано-диверсифицированной компании в пищевой промышленности. Рассмотрены стратегические ориентиры и корневые компетенции компании в данной отрасли. Проведена оценка возможных эффектов: экономических, социальных, экологических, синергетических от стратегических действий. Проанализированы интересы потребителей («качество-цена») по основным видам продукции, представлен алгоритм разработки и реализации стратегии данной компании, отличающийся от существующих учетом интересов ключевых стейкхолдеров компании. На основе алгоритма разработаны стратегические действия по углублению интеграции и расширению диверсификации интегрировано-диверсифицированной компании региона с учетом интересов акционеров и потребителей. При этом предлагаемые стратегические действия оцениваются при помощи количественных и качественных показателей оценки эффектов для интегрировано-диверсифицированной компании.
\end{abstract}

кЛЮЧЕВЫЕ СЛОВА. Пищевая промышленность; интеграция; диверсификация; интересы ключевых стейкхолдеров; стратегические действия.

ИНФОРМАЦИЯ О СТАТЬЕ. Дата поступления 25 января 2016 г.; дата принятия к печати 26 февраля 2016 г.; дата онлайн-размещения 31 марта 2016 г.

M. F. Tyapkina

A. A. Ezhevsky Irkutsk State Agricultural University, Molodyozhny Settlement, Russian Federation

S. I. Vinokurov

A. A. Ezhevsky Irkutsk State Agricultural University, Molodyozhny Settlement, Russian Federation

\section{COMBINATION OF STRATEGIC AND STAKEHOLDERS' APPROACHES TO DEVELOPING INTEGRATED DIVERSIFIED COMPANIES IN FOOD INDUSTRY}

\begin{abstract}
The article describes problems of developing food industry companies. It substantiates using a combination of strategic and stakeholders' approaches to developing an integrated diversified company in food industry. It considers strategic milestones and root competences in this industry. It carries out an assessment of possible effects: economic, social, ecological, synergetic ones resulting from strategic actions. The article analyses consumers' interests ( «quality-price») in regard of main types of products, presents an algorithm of developing and implementing the strategy of the given company differing from the existing ones by considering for the interests of the company's key stakeholders. On the basis of the algorithm, it develops strategic actions in deepening integration and expanding diversification of the regional integrated diversified company in view of the interests of the shareholders and consumers. At that,
\end{abstract}

\section{Baikal Research Journal}


the proposed strategic actions are assessed with help of quantitative and qualitative indicators of estimating the effects for the integrated diversified company.

KEYWORDS. Food industry; integration; diversification; interests of key stakeholders; strategic actions.

ARTICLE INFO. Received January 28, 2016; accepted February 26, 2016; available online March 31, 2016.

В пищевой отрасли существует ряд проблем, определяющих тенденции развития интегрировано-диверсифицированных компаний. Современные исследования указывают на такие проблемы развития предприятий пищевой промышленности, как отставание в техническом и технологическом обеспечении процесса производства пищевых продуктов (в том числе при производстве сырья), сильная зависимость пищевой промышленности от импорта сырья и готовой продукции, низкая загрузка производственных мощностей собственными заказами, недостаточное количество отечественных научных разработок и готовых решений в области биотехнологий, агрохимии, семеноводства, выведения пород для улучшения качества сырья и др. [1-3]. Выявленные проблемы тормозят развитие интегрировано-диверсифицированных компаний пищевой промышленности.

Для успешного развития интегрировано-диверсифицированной компании СХОАО «Белореченское» необходимо использовать современные инструменты и методы стратегического развития. В настоящее время существуют разнообразные подходы к управлению компанией: системный, стратегический, маркетинговый, функциональный, динамический, воспроизводственный, процессный, нормативный, количественный, административный, поведенческий, ситуационный, стейкхолдерский, стокхолдерский, программно-целевой, проектный и др. [4]. Их независимое применение и использование в различных комбинациях обеспечивают достижение разных целей и эффектов.

Не существует одного универсального подхода, способного предоставить набор инструментов и методов для решения всего многообразия проблем развития компаний. Нами предлагается использовать комбинацию стейкхолдерского и стратегического подходов к развитию интегрировано-диверсифицированной компании в пищевой промышленности. По нашему мнению, для разработки и реализации стратегии интегрировано-диверсифицированной компании необходимо использовать комбинацию подходов, дающую преимущества в обеспечении непрерывности развития компании, где стратегический подход позволяет сломать сложившиеся негативные тенденции в отрасли [5], а учет интересов стейкхолдеров - заинтересовать всех участников деятельности в достижении стратегических целей.

В современных работах российских и зарубежных авторов [1;6] преимущественное внимание уделяется ключевым стейкхолдерам - владельцам (акционерам) и топ-менеджерам компании. Интересы других стейкхолдеров не подвергаются глубокому анализу и недостаточно учитываются при стратегическом развитии компании, хотя формально клиентоориентированный подход провозглашен. Имеется очень немного работ, где анализируются интересы потребителей с точки зрения соотношения «цена-качество», но при этом на первое место поставлена цена [7].

В пищевой промышленности, на наш взгляд, необходимо учитывать такого ключевого стейкхолдера, как потребитель продукции [8]. Его сила в том, что он перестает покупать продукцию, как только его не устраивает соотношение «качество-цена», а интерес усиливается, если предлагается полезная экологически чистая продукция, и резко снижается, если он узнает, что продукция вредна для его здоровья. Эти обстоятельства учтены нами при разработке алгоритма (рис.).

\section{Baikal Research Journal}




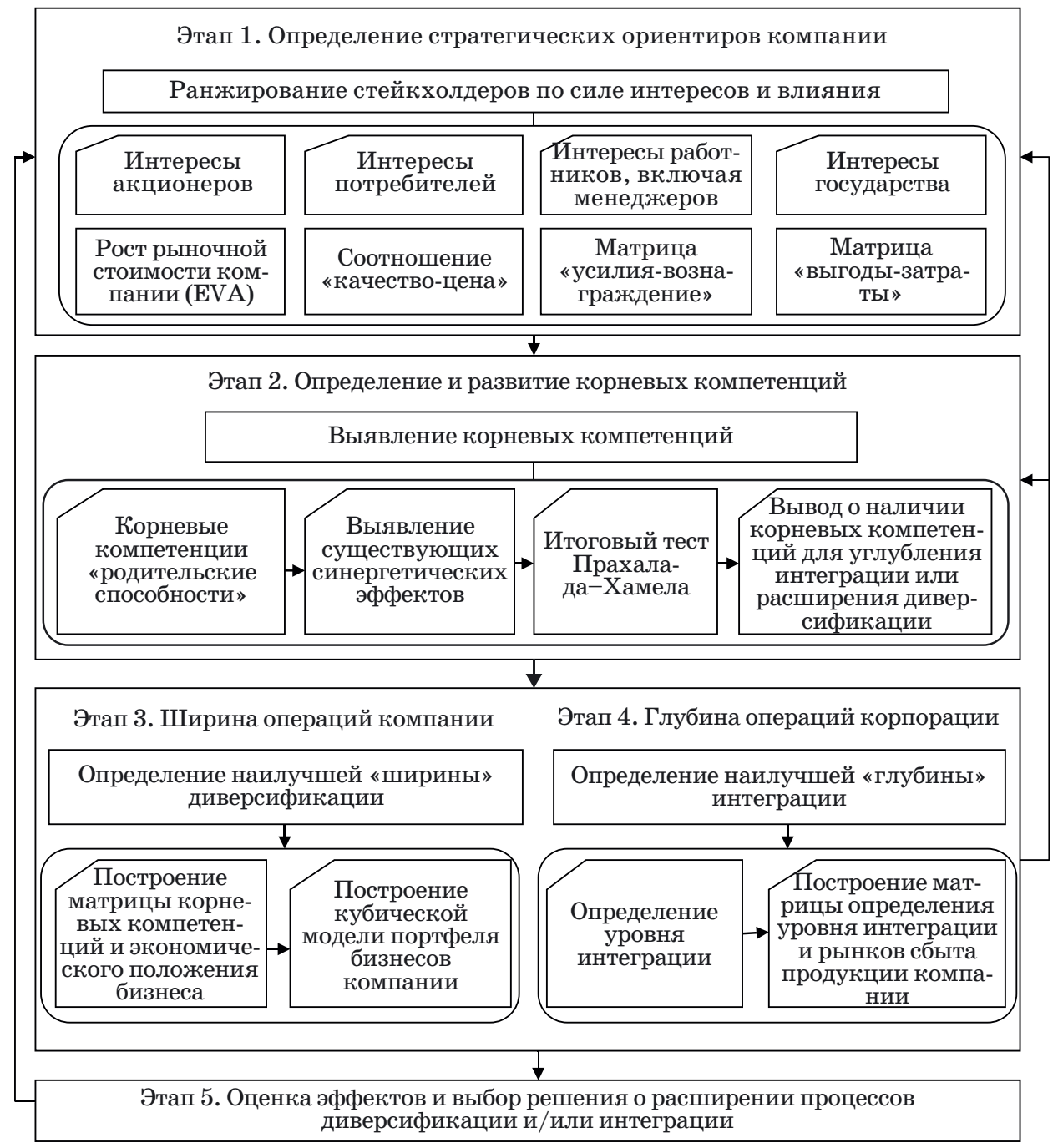

Алгоритм разработки и реализации стратегии

интегрировано-диверсифищированной компании пищевой промышленности

В предлагаемом алгоритме развиты положения И. Б. Гуркова [9] в части учета интересов акционеров, потребителей и других стейкхолдеров применительно к интегрировано-диверсифицированным компаниям пищевой промышленности. С помощью ранжирования стейкхолдеров по степени влияния и интересов определяются стратегические ориентиры развития компании, которые транслируются через анализ «глубины» интеграции и «ширины» диверсификации в предложения по выбору решения относительно дальнейшего расширения диверсификации и/или углубления интеграции.

Для обоснования действий по разработке и реализации стратегического развития интегрировано-диверсифицированной компании СХОАО «Белореченское» воспользуемся разработанным алгоритмом.

Этап 1. Определение стратегических ориентиров колпании - выявляются интересы стейкхолдеров и их главные цели.

\section{Baikal Research Journal}

электронный научный журнал Байкальского государственного университета 
На основе матрицы определения степени взаимного влияния компании и стейкхолдеров по оценкам экспертов установлено, что у потребителей продукции компании СХОАО «Белореченское» высокий уровень интереса и могущества, т. е. потребители заинтересованы потреблять продукцию компании и при этом компания зависима от интересов потребителей, следовательно, их можно отнести к группе ключевых стейкхолдеров компании. Экспертами также обнаружена степень влияния других стейкхолдеров на развитие компании. В результате анализа уровня интереса и могущества стейкхолдеров, оказывающих влияние на компанию, определены основные приоритеты ключевых игроков (табл. 1), которыми являются акционеры и потребители.

Таблица 1

\section{Определение основных приоритетов ключевых стейкхолдеров} СХОАО "Белореченское»

\begin{tabular}{|l|l|l|l|}
\hline \multicolumn{1}{|c|}{ Тип стейкхолдера } & $\begin{array}{l}\text { Взаимозависимость фирмы } \\
\text { и стейкхолдера }\end{array}$ & \multicolumn{1}{|c|}{ Степень влияния } & \multicolumn{1}{|l}{ Приоритеты } \\
\hline Потребители & Сила стейкхолдера & $\begin{array}{l}\text { Любопытствующие, } \\
\text { ключевые игроки }\end{array}$ & Качество-цена \\
\hline Акционеры & $\begin{array}{l}\text { Высокая взаимозависи- } \\
\text { мость }\end{array}$ & Ключевые игроки & $\begin{array}{l}\text { Рост стоимости ком- } \\
\text { пании }\end{array}$ \\
\hline $\begin{array}{l}\text { Работники, включая } \\
\text { менеджеров }\end{array}$ & Сила фирмы & $\begin{array}{l}\text { Любопытствующие } \\
\text { игроки }\end{array}$ & Рост доходов \\
\hline Государство & Сила стейкхолдера & Спящие чудовища & Налоги \\
\hline
\end{tabular}

В результате оценки интересов акционеров компании СХОАО «Белореченское» выявлены возможные риски в деятельности компании в будущем с учетом современных вызовов. Так, одним из вызовов развития интегрировано-диверсифицированной компании отмечается недозагруженность производственных мощностей собственными заказами. Загруженность мощностей напрямую связана с возможностями компании реализовать свою продукцию на рынке [10]. В настоящее время экономисты [11] отмечают падение покупательской способности населения и, как следствие, возникновение риска снижения объемов продаж продукции СХОАО «Белореченское». Под влияние риска в большей степени, по оценкам менеджмента компании [12], может попасть продукция молочного направления, а именно те товары, в составе которых используются ингредиенты, не попавшие под действие санкций (пальмовое масло), например, сливочное масло, йогурт, кефир, сметана или творог. Экспертами [13] также отмечается высокая доля импорта практически на всех этапах технологического цикла производства пищевых продуктов, начиная с семян и пород животных (птиц) и заканчивая упаковкой. Зависимость компании от этих составляющих также волнует акционеров.

С целью исследования интересов потребителей продукции компаний пищевой промышленности, как одних из важнейших ключевых стейкхолдеров, было проведено социологическое исследование в форме прямого анкетирования потребителей. Репрезентативность выборки соблюдалась путем включения в состав объектов обследования различных городов, районных центров, сельских муниципальных образований, отличающихся по местоположению, а также потребителей с разным уровнем доходов, вкусовыми предпочтениями, возрастными группами и т. д. В проводимом исследовании приняли участие 400 потребителей, находящихся как в крупных городах, так и в других населенных пунктах Иркутской области.

Цель данного исследования - сформулировать выводы, характеризующие предпочтения потребителей основных продуктов питания, в потреблении качественной, недорогой, экологически чистой продукции.

\section{Baikal Research Journal}


На основе анкетирования рассчитаны итоговые таблицы для основных продуктов питания компании (табл. 2-6). В результатах анкетирования не учитывались данные по потребителям, которые покупают продукцию личных подсобных хозяйств.

Анализ интересов потребителей по матрице «качество-цена» по основным видам продукции компании показал, что СХОАО «Белореченское» предлагает потребителю более качественную продукцию по сравнению с конкурентами, но при этом заметно дорогую (см. табл. 2). Например, такой продукт, как сливочное масло, не пользуется популярностью у населения из-за высокой цены. Продукт не выдерживает ценовую конкуренцию в сравнении с аналогами, так как в процессе его производства используются натуральные ингредиенты и себестоимость получается выше товаров-конкурентов, в процессе производства которых используются более дешевые ненатуральные ингредиенты (пальмовое масло). В соответствии с этим предлагается оценить возможность расширения ассортимента выпускаемой продукции молочного направления (производство сыра) за счет загрузки имеющихся недозагруженных мощностей компании (молочное стадо), а также применять часть сырья используемого при производстве сливочного масла.

При возможном увеличении объемов производства овощной и мясной продукции компания может столкнуться с проблемой повышения накладных расходов, связанных с хранением и реализацией этой скоропортящейся продукции. Поэтому в результате опроса потребителей были выявлены возможные потребности в потреблении консервированной продукции СХОАО «Белореченское». Проанализировав результаты интересов потребителей, предлагается оценить возможности расширения уровня диверсификации за счет производства консервированной плодовоовощной и мясной продукции (паштеты, консервы, соусы и т. д.).

Таблица 2

Сводная таблица результатов анализа продукции СХОАО «Белореченское» по соотночению «качество-иена»

\begin{tabular}{|c|c|c|c|}
\hline $\begin{array}{l}\text { Продук- } \\
\text { ция }\end{array}$ & $\begin{array}{l}\text { Соотношение } \\
\text { «цена-качество» }\end{array}$ & $\begin{array}{c}\text { Необходимость } \\
\text { в изменениях }\end{array}$ & Предлагаемые действия \\
\hline Яйцо & $\begin{array}{l}\text { Соответствие высокой } \\
\text { цены и высокого качества }\end{array}$ & Стоимость & $\begin{array}{l}\text { Создание продукта с заданными пара- } \\
\text { метрами качества и более низкой ценой }\end{array}$ \\
\hline Молоко & $\begin{array}{l}\text { Не соответствует ожидани- } \\
\text { ям потребителей по цене }\end{array}$ & Стоимость & $\begin{array}{l}\text { Действия, направленные на снижение } \\
\text { себестоимости продукции }\end{array}$ \\
\hline Творог & $\begin{array}{l}\text { Соответствие высокой } \\
\text { цены и высокого качества }\end{array}$ & Стоимость & $\begin{array}{l}\text { Создание продукта с заданными пара- } \\
\text { метрами качества и более низкой ценой }\end{array}$ \\
\hline Сметана & $\begin{array}{l}\text { Соответствие высокой } \\
\text { цены и высокого качества }\end{array}$ & Качество & $\begin{array}{l}\text { Создание продукта с заданными пара- } \\
\text { метрами качества и более низкой ценой }\end{array}$ \\
\hline Масло & $\begin{array}{l}\text { Не соответствует ожидани- } \\
\text { ям потребителей по цене }\end{array}$ & Стоимость & $\begin{array}{l}\text { Мероприятия, направленные на сниже- } \\
\text { ние себестоимости продукции }\end{array}$ \\
\hline Колбасы & $\begin{array}{l}\text { Соответствие средней цены } \\
\text { и высокого качества }\end{array}$ & Нет & Нет \\
\hline
\end{tabular}

Таким образом, в результате анализа интересов акционеров и потребителей нами были сформулированы предложения, заключающиеся в оценке возможностей дальнейшего углубления интеграции, например создание лаборатории по выведению эффективных сортов выращиваемых культур и используемых пород животных (птиц), и (или) расширения диверсификации, например создание цеха по производству сыра и др. (см. табл. 5).

Этап 2. Определение и развитие корневых колпетениий - устанавливается и используется возможный синергетический эффект от взаимодействия различных видов деятельности компании, делается вывод.

\section{Baikal Research Journal}


В результате опроса, проведенного среди топ-менеджеров СХОАО «Белореченское», были выявлены корневые компетенции (см. табл. 3), которые проверили по тесту «Прахалада-Хамела» на предмет соответствия утверждениям: обеспечивают ли выявленные компетенции потенциальный доступ на разнообразные рынки, влияют ли на качество конечной продукции компании и возможности скопировать их конкурентами. Проведенный анализ доказал, что это корневые компетенции.

Таблица 3

Выявление корневых компетенций СХОАО «Белореченское»

\begin{tabular}{|l|l|l|}
\hline \multicolumn{1}{|c|}{ Ноу-хау } & \multicolumn{1}{|c|}{ Системы } & \multicolumn{1}{|c|}{ Особые отношения } \\
\hline $\begin{array}{l}\text { Умение встроить входящий бизнес в } \\
\text { действующую систему контрактов и } \\
\text { особо выгодных заказов }\end{array}$ & $\begin{array}{l}\text { Аккумуляция и инвестирование } \\
\text { финансовых ресурсов }\end{array}$ & $\begin{array}{l}\text { Политическая под- } \\
\text { держка }\end{array}$ \\
\hline $\begin{array}{l}\text { Максимальная загрузка мощностей } \\
\text { по основному виду продукции }\end{array}$ & $\begin{array}{l}\text { Взаимосвязанные сбыт и дистри- } \\
\text { буция выпускаемой продукции }\end{array}$ & $\begin{array}{l}\text { Опытная команда } \\
\text { специалистов }\end{array}$ \\
\hline $\begin{array}{l}\text { Использование прогрессивных тех- } \\
\text { нологий в бизнесе }\end{array}$ & $\begin{array}{l}\text { Наличие корневого бизнеса, } \\
\text { вокруг которого происходит } \\
\text { развитие компании }\end{array}$ & $\begin{array}{l}\text { Преемственность по- } \\
\text { колений и подготовка } \\
\text { молодых специалистов }\end{array}$ \\
\hline $\begin{array}{l}\text { Применение технологий безотход- } \\
\text { ного производства }\end{array}$ & $\begin{array}{l}\text { Использование синергетических } \\
\text { эффектов от диверсификации и } \\
\text { связанной диверсификации }\end{array}$ & $\begin{array}{l}\text { Взаимодействие с } \\
\text { аграрным универси- } \\
\text { тетом }\end{array}$ \\
\hline
\end{tabular}

При этом в СХОАО «Белореченское» диверсификация связана с максимальным использованием синергетических эффектов (см. табл. 4).

Таблица 4

Классификация существующих синергетических эффектов

в СХОАО «Белореченское»

\begin{tabular}{|l|l|}
\hline \multicolumn{1}{|c|}{ Вид синергии } & \multicolumn{1}{|c|}{ Форма реализации эффекта } \\
\hline Политическая & $\begin{array}{l}\text { Наличие наработанных связей и контактов и использование этих отноше- } \\
\text { ний на все входящие бизнесы }\end{array}$ \\
\hline Финансовая & Единый бюджет развития компании в целом \\
\hline Маркетинговая & $\begin{array}{l}\text { Идентификация новых направлений деятельности компании и новых рын- } \\
\text { ков, отлаженная система маркетинга для всей компании в целом }\end{array}$ \\
\hline Производственная & $\begin{array}{l}\text { Замкнутый цикл производства от производства сырья до конечного про- } \\
\text { дукта }\end{array}$ \\
\hline Инновационная & - \\
\hline Кадровая & $\begin{array}{l}\text { Опытная команда специалистов с разнообразными способностями, при- } \\
\text { менение знаний, опыта и профессиональных навыков для разных видов } \\
\text { бизнеса компании }\end{array}$ \\
\hline
\end{tabular}

В дальнейшем предполагается использование выявленных видов синергии для оценки эффектов от мероприятий по углублению интеграции и расширению диверсификации компании.

Этап 3. Определение «ширины» охвата различных рынков операцияли компании - выявление наилучшей «ширины» диверсификации. В результате анализа ширины охвата операций СХОАО «Белореченское» нами сделан вывод об оптимальном уровне диверсификации компании. На предприятии существует корневой бизнес - производство яйца, вокруг которого с помощью использования синергетических (финансовых, производственных, маркетинговых и кадровых) эффектов успешно работают и развиваются другие направления деятельности. СХOAО «Белореченское» является компанией, которая использует стратегию сфокусированной диверсификации (доля продаж внутри отрасли пищевой продукции более 95 \% ) и в результате этого имеет оптимальную ширину охвата операций и рынка. Однако для

\section{Baikal Research Journal}

электронный научный журнал Байкальского государственного университета 
повышения устойчивости бизнеса в современных условиях по производству молочной продукции необходимо загрузить недозагруженные мощности по переработке молока, так, например, одним из дальнейших направлений развития может быть производство сыров.

Этап 4. Определение функционирования интегрировано-диверсифицированной колпании - выявление наилучшей «глубины» интеграции и ширины диверсификации. На основе анализа интересов ключевых компетенций и определения углубления интеграции и расширения диверсификации (см. табл. 5) был сделан вывод о необходимости укрепления интеграционных процессов, связанных с реализацией готовой продукции всей компании, и развития в сфере высоких технологий и наукоемкого производства на основе налаженных зарубежных и отечественных связей с учебными заведениями в области научных разработок. По нашему мнению, необходимо также развивать процессы диверсификации с учетом имеющихся направлений деятельности компании. При этом интегрировано-диверсифицированная компания СXОАО «Белореченское» испытывает проблемы загрузки имеющихся мощностей и в связке с новыми вызовами, стоящими перед отраслью и компанией в современных условиях, требует развития тех производств, где необходимо замещение импортных товаров продукцией отечественного производителя. Так, например, для загрузки имеющихся мощностей по продуктивному молочному стаду возможно наладить производство сыра из молока, которое не реализуется в необходимые сроки, или молока, вернувшегося из магазинов как возврат.

Предлагаемые стратегические действия по углублению интеграции и расширению диверсификации с учетом интересов акционеров и потребителей СХОАО «Белореченское»

\begin{tabular}{|c|c|c|}
\hline $\begin{array}{c}\text { Действия, направленные на рас- } \\
\text { ширение процессов интеграции } \\
\text { и диверсификации }\end{array}$ & Решение проблемы в отрасли & $\begin{array}{c}\text { Интересы } \\
\text { стейкхолдеров }\end{array}$ \\
\hline $\begin{array}{l}\text { Создание линии по производ- } \\
\text { ству сыра (процессы диверсифи- } \\
\text { кации) }\end{array}$ & $\begin{array}{l}\text { Импортозамещение, продовольственная } \\
\text { безопасность, загрузка мощностей }\end{array}$ & \multirow{5}{*}{$\begin{array}{l}\text { Потребители - но- } \\
\text { вый продукт, каче- } \\
\text { ство, цена, время; } \\
\text { акционеры - повы- } \\
\text { шение конкуренто- } \\
\text { способности и сто- } \\
\text { имости компании; } \\
\text { работники, включа } \\
\text { менеджмент - рост } \\
\text { дохода, уверенность } \\
\text { в будущем; государ- } \\
\text { ство - снижение } \\
\text { безработицы, увели- } \\
\text { чение поступления } \\
\text { налогов, развитие } \\
\text { инфраструктуры }\end{array}$} \\
\hline $\begin{array}{l}\text { Производство детского питания } \\
\text { (процессы диверсификации) }\end{array}$ & $\begin{array}{l}\text { Продовольственная безопасность, за- } \\
\text { грузка мощностей }\end{array}$ & \\
\hline $\begin{array}{l}\text { Создание научной лаборатории } \\
\text { по выведению пород животных и } \\
\text { селекции сортов растений (про- } \\
\text { цессы интеграции) }\end{array}$ & $\begin{array}{l}\text { Отсутствие отечественных научных раз- } \\
\text { работок и готовых решений для пищевой } \\
\text { промышленности, зависимость пищевой } \\
\text { промышленности от импорта сырья }\end{array}$ & \\
\hline $\begin{array}{l}\text { Создание линии по производству } \\
\text { лечебной косметики (процессы } \\
\text { интеграции и диверсификации) }\end{array}$ & $\begin{array}{l}\text { Импортозамещение, безотходное произ- } \\
\text { водство, загрузка мощностей }\end{array}$ & \\
\hline $\begin{array}{l}\text { Создание линии по производству } \\
\text { консервированной плодовоовощ- } \\
\text { ной и мясной продукции }\end{array}$ & $\begin{array}{l}\text { Импортозамещение, продовольственная } \\
\text { безопасность, безотходное производ- } \\
\text { ство, загрузка мощностей }\end{array}$ & \\
\hline
\end{tabular}

Предлагаемые направления углубления интеграции и расширения диверсификации с учетом интересов акционеров и потребителей СХ ОАО «Белореченское» необходимо оценить с помощью количественных и качественных показателей оценки эффектов для интегрировано-диверсифицированной компании. Нами выявлено, что одним из приоритетных направлений с точки зрения загрузки недозагруженных производственных мощностей компании является молочное направление и в этой связи имеет особую актуальность проект по производству и реализации сыра, что также очень важно при решении вопросов по обеспечению продовольственной безопасности и импортозамещения.

\section{Baikal Research Journal}

электронный научный журнал Байкальского государственного университета 
Оиенка качественных показателей возможных әффектов от стратегических действий

\begin{tabular}{|c|c|c|c|c|c|}
\hline $\begin{array}{l}\text { Возможные } \\
\text { эффректы }\end{array}$ & Показатели & \begin{tabular}{|c|} 
Коэффии- \\
циент \\
значи- \\
мости \\
\end{tabular} & $\begin{array}{c}\text { Каче- } \\
\text { ствен- } \\
\text { ная } \\
\text { оценка }\end{array}$ & $\begin{array}{c}\text { Шкала } \\
\text { оце- } \\
\text { нок, } \\
\text { баллы }\end{array}$ & $\begin{array}{c}\text { Шкала } \\
\text { оценок с } \\
\text { учетом зна- } \\
\text { чимости } \\
\end{array}$ \\
\hline \multicolumn{4}{|l|}{ Экономические: } & 4 & 0,32 \\
\hline \multirow{4}{*}{$\begin{array}{l}\text { Рост эффек- } \\
\text { тивности де- } \\
\text { ятельности } \\
\text { компании }\end{array}$} & Снижение издержек & 0,09 & Да & 1 & 0,09 \\
\hline & Повышение рентабельности активов & 0,04 & Да & 1 & 0,04 \\
\hline & Рост оборачиваемости активов & 0,05 & Да & 1 & 0,05 \\
\hline & Загрузка производственных мощностей & 0,08 & Полная & 1 & 0,08 \\
\hline \multirow{3}{*}{$\begin{array}{l}\text { Рост конку- } \\
\text { рентоспо- } \\
\text { собности }\end{array}$} & Повышение качества продукции & 0,06 & Нет & 0 & 0 \\
\hline & Снижение цены для потребителей & 0,02 & Нет & 0 & 0 \\
\hline & $\begin{array}{l}\text { Сокращение длительности производ- } \\
\text { ственного цикла }\end{array}$ & 0,06 & Да & 1 & 0,06 \\
\hline \multicolumn{4}{|l|}{ Социальные: } & 3 & 0,11 \\
\hline \multirow{4}{*}{$\begin{array}{l}\text { Улучшение } \\
\text { социаль- } \\
\text { но-эконо- } \\
\text { мической } \\
\text { ситуации в } \\
\text { регионе }\end{array}$} & $\begin{array}{l}\text { Создание инфраструктурных объектов } \\
\text { (учреждения здравоохранения, культу- } \\
\text { ры и т.д.) }\end{array}$ & 0,02 & Нет & 0 & 0 \\
\hline & Уверенность работников в будущем & 0,07 & Нет & 0 & 0 \\
\hline & $\begin{array}{l}\text { Повышение уровня образования, ква- } \\
\text { лификации работников }\end{array}$ & 0,04 & Есть & 1 & 0,04 \\
\hline & Создание рабочих мест & 0,02 & Есть & 1 & 0,02 \\
\hline \begin{tabular}{l|} 
Натураль- \\
ные продук- \\
ты питания
\end{tabular} & Отсутствие искусственных добавок & 0,05 & Есть & 1 & 0,05 \\
\hline \multicolumn{4}{|l|}{ Экологические: } & 2 & 0,08 \\
\hline \multirow{2}{*}{$\begin{array}{l}\text { Снижение } \\
\text { вредного } \\
\text { воздействия } \\
\text { на окружа- } \\
\text { ющую среду }\end{array}$} & Наличие очистных сооружений & 0,01 & Нет & 0 & 0 \\
\hline & $\begin{array}{l}\text { Отсутствие в производстве запрещен- } \\
\text { ных удобрений, стимуляторов роста и } \\
\text { т. д. } \\
\end{array}$ & 0,05 & Да & 1 & 0,05 \\
\hline $\begin{array}{l}\text { Безотходное } \\
\text { производ- } \\
\text { ство }\end{array}$ & $\begin{array}{l}\text { Наличие (совершенствование) техно- } \\
\text { логии переработки отходов пищевого } \\
\text { производства }\end{array}$ & 0,03 & Да & 1 & 0,03 \\
\hline \begin{tabular}{l|} 
Охрана \\
окружаю- \\
щей среды \\
\end{tabular} & $\begin{array}{l}\text { Снижение негативного воздействия ма- } \\
\text { шин и оборудования на окружающую } \\
\text { экосистему }\end{array}$ & 0,01 & Нет & 0 & 0 \\
\hline \multicolumn{4}{|c|}{ Синергетические: } & 5 & 0,38 \\
\hline $\begin{array}{l}\text { Производ- } \\
\text { ственные }\end{array}$ & $\begin{array}{l}\text { Наличие связанных процессов при про- } \\
\text { изводстве продукции }\end{array}$ & 0,09 & Есть & 1 & 0,09 \\
\hline Финансовые & $\begin{array}{l}\text { Возможности взаимного использования } \\
\text { денежных средств в разных финансо- } \\
\text { вых циклах }\end{array}$ & 0,08 & $\begin{array}{l}\text { Высо- } \\
\text { кие }\end{array}$ & 2 & 0,08 \\
\hline Кадровые & $\begin{array}{l}\text { Возможности взаимного использова- } \\
\text { ния опыта, знаний, профессиональных } \\
\text { навыков для входящего бизнеса }\end{array}$ & 0,06 & Есть & 1 & 0,06 \\
\hline $\begin{array}{l}\text { Управленче- } \\
\text { ские }\end{array}$ & $\begin{array}{l}\text { Возможности применения уникальных } \\
\text { управленческих решений для входяще- } \\
\text { го бизнеса }\end{array}$ & 0,07 & Есть & 1 & 0,07 \\
\hline \multicolumn{2}{|c|}{ Итоговая сумла } & 1,00 & - & 14 & 0,89 \\
\hline
\end{tabular}

\section{Baikal Research Journal}


Для принятия решения о выборе приоритетного направления расширения операций по диверсификации и/или интеграции необходимо оценить качественные показатели эффектов от реализации проекта. Виды эффектов группируются в таблице, каждому из них присваивается бальная оценка и коэффициент значимости, так как они различаются в зависимости от различных факторов (см. табл. 6).

В результате оценки качественных показателей от внедрения проекта по производству сыра эффекты были сгруппированы по функциональному признаку на экономические, социальные, синергетические и экологические. В конечном итоге выявили, что сумма эффектов равна 14 , а с учетом коэффициента значимости $-0,89$ из 1,00. Аналогично производится оценка количественных и качественных показателей эффектов от внедрения других проектов и на основании их сравнения делаются предложения по возможной их реализации для компании. Для обоснованности выбора проектов экспертным путем разрабатывается шкала оценки качественных эффектов с учетом коэффициента значимости:

- уровень достижения эффектов высокий $-0,71-1,00$;

- уровень достижения эффектов средний $-0,41-0,70$;

- уровень достижения эффектов низкий - 0-0,4.

Согласно предлагаемой шкале уровень достижения эффектов по данному проекту высокий $-0,89$ баллов.

Оцениваемое направление позволяет в настоящее время наиболее полно отвечать на вызовы и связанные с ними проблемы, ставящиеся перед интегрировано-диверсифицированной компанией пищевой промышленности, и таким образом повышать ее устойчивость и конкурентоспособность.

\section{Список использованной литературы}

1. Винокуров Г. М. Состояние основных фондов и источники их обновления в сельском хозяйстве / Г. М. Винокуров, С. И. Винокуров, Т. В. Леус. - Иркутск : Изд-во Иркут. гос. с.-х. акад., 2015. - 141 с.

2. Последствия вступления России во Всемирную торговую организацию для региональной экономики / А. П. Киреенко, Д. Ю. Федотов, Л. В. Санина [и др.]. - Иркутск : Изд-во БГУЭП, 2013. - 252 с.

3. Тараканов М. А. Пищевая промышленность Иркутской области: проблемы, перспективы / М. А. Тараканов // Экономист. - 2014. - № 6. - С. 61-70.

4. Стратегическое управление экономикой на разных уровнях организации хозяйства / под ред. А. Ф. Шуплецова. - Иркутск : Изд-во БГУЭП, 2005. - 464 с.

5. Винокуров С. И. Корпоративные стратегии развития диверсифицированных компаний / С. И. Винокуров // Механизм деятельности хозяйствующих организаций в рыночных условиях : материалы междунар. науч.-практ. конф., 18 мая 2007 г. / под ред. А. Ф. Шуплецова. - Иркутск : Изд-во БГУЭП, 2007. - С. 110-113.

6. Каплан Р. Стратегические карты. Трансформация нематериальных активов в материальные результаты : пер. с англ. / Р. Каплан, Д. Нортон. - М. : Олимп-Бизнес, 2005. $-512 \mathrm{c}$.

7. Юшкова И. Е. Некоторые аспекты соотношения «цена-качество» / И. Е. Юшкова // Экономика и предпринимательство. - 2015. - № 7. - С. 853-857.

8. Винокуров С. И. Интересы субъектов бизнеса при формировании предпринимательской стратегии / С. И. Винокуров // Стратегическое и тактическое планирование в компании : сб. науч. тр. / под ред. А. Ф. Шуплецова. - Иркутск : Изд-во БГУЭП, 2013. - 116 с. $320 \mathrm{c}$

9. Гурков И. Б. Стратегия и структура корпорации / И. Б. Гурков. - М. : Дело, 2006. -

10. Светник Т. В. Стратегические альянсы и конкурентные стратегии в зарубежном бизнесе / Т. В. Светник // Социальные и экономические аспекты развития бизнеса : междунар. науч.-практ. конф. Иркутск, 6 апр. 2010 г. - Иркутск : Изд-во Иркут. гос. ун-та, 2010. C. $280-285$.

\section{Baikal Research Journal}


11. Баймашев Д. Наша цель - устойчивое развитие аграрного комплекса / Д. Баймашев // Под знаком качества : информ.-аналит. вып. - 2015. - № 128 (1444). - С. 2.

12. Пухмахтерова Т. С. Сельское хозяйство - это отрасль будущего / Т. С. Пухмахтерова // Областная газета. - 2013. - 13 дек.

13. Ермак С. Продовольственный оптимизм / С. Ермак // Эксперт. - 2015. № 41 (960). - C. 20 .

\section{References}

1. Vinokurov G. M., Vinokurov S. I., Leus T. V. Sostoyanie osnovnykh fondov i istochniki ikh obnovleniya $v$ sel'skom khozyaistve [Status of fixes assets and sources of their renewal in agriculture]. Irkutsk State Academy of Agriculture Publ., 2015. 141 p.

2. Kireyenko A. P., Fedotov D. Yu., Sanina L. V. et al. Posledstviya vstupleniya Rossii vo Vsemirnuyu torgovuyu organizatsiyu dlya regional'noi ekonomiki [The consequences of Russia's entry into the World Trade Organization for the regional economy]. Irkutsk, Baikal State University of Economics and Law Publ., 2013. 252 p.

3. Tarakanov M. A. Food industry in Irkutsk Oblast: problems, prospects. Ekonomist, 2014, no. 6, pp. 61-70. (In Russian).

4. Shupletsov A. F. (ed.). Strategicheskoe upravlenie ekonomikoi na raznykh urovnyakh organizatsii khozyaistva [Strategic control of economy at various levels of performance management]. Irkutsk, Baikal State University of Economics and Law Publ., 2005. 463 p.

5. Vinokurov G. M. Corporative strategies of developing diversified companies. In Shupletsov A. F. (ed.). Mekhanizm deyatel'nosti khozyaistvuyushchikh organizatsiiv rynochnykh usloviyakh. Materialy mezhdunarodnoi nauchno-prakticheskoi konferentsii, 18 maya 2007 g. [Activity mechanism of economic organizations in terms of market. Materials of International Research Conference, May 18, 2007]. Irkutsk, Baikal State University of Economics and Law Publ., 2007, pp. 110-113. (In Russian).

6. Kaplan Robert, Norton David. Strategicheskie karty. Transformatsiya nematerial'nykh aktivov $v$ material'nye rezul'taty [Strategic maps. Transformation of non-material assets into material results]. Moscow, Olimp-Biznes Publ., 2005. 512 p.

7. Yushkova I. E. Some aspects of the correlation "price-quality» Ekonomika i predprinimatel'stvo = Economics and Entrepreneurship, 2015, no. 7, pp. 853-857. (In Russian).

8. Vinokurov G. M. Interests of business entities in developing entrepreneurial strategy. In Shupletsov A. F. (ed.). Strategicheskoe i takticheskoe planirovanie v kompanii [Strategic and tactical planning in the company]. Irkutsk, Baikal State University of Economics and Law Publ., 2013. 116 p. (In Russian).

9. Gurkov I. B. Strategiya i struktura korporatsii [Corporation's strategy and structure]. Moscow, Delo Publ., 2006. 320 p.

10. Svetnik T. V. Strategic alliances and competitive strategies in foreign business. Sotsial'nye i ekonomicheskie aspekty razvitiya biznesa. Materialy mezhdunarodnoi nauchno-prakticheskoi konferentsii, Irkutsk, 6 aprelya 2010 g. [Social and economic aspects of business development. Materials of International Research Conference, Irkutsk, April 6, 2010]. Irkutsk State University Publ., 2010, pp. 280-285. (In Russian).

11. Baimashev D. Our goal is sustainable development of the agrarian complex. Pod znakom kachestva $=$ Under the sign of quality, 2015, no. 128 (1444), p. 2. (In Russian).

12. Pukhmakhterova T. S. Agriculture is an industry of the future. Oblastnaya, 2013, December 13. (In Russian).

13. Ermak S. Food optimism. Ekspert = Expert, 2015, no. 41 (960), p. 20. (In Russian).

\section{Информация об авторах}

Тяпкина Мария Федоровна - кандидат экономических наук, доцент, заведующий кафедрой финансов и анализа экономического факультета, Иркутский государственный аграрный университет им. А. А. Ежевского, 664038, Иркутская область, Иркутский район, пос. Молодежный, e-mail: mft74@mail.ru.

Винокуров Сергей Иннокентьевич - ассистент, кафедра финансов и анализа, Иркутский государственный аграрный университет им. А. А. Ежевского, 664038, Иркутская область, Иркутский район, пос. Молодежный, e-mail: vinokurovsi@mail.ru.

\section{Baikal Research Journal}




\section{Authors}

Maria F. Tyapkina - PhD in Economics, Associate Professor, Head of Chair of Finance and Analysis, Faculty of Economics, A. A. Ezhevsky Irkutsk State Agricultural University, Molodezhny Settlement, Irkutsk District, 664038, Irkutsk Oblast, Russian Federation; e-mail: mft74@mail.ru.

Sergey I. Vinokurov - Teaching Assistant, Chair of Chair of Finance and Analysis, Faculty of Economics, A. A. Ezhevsky Irkutsk State Agricultural University, Molodezhny Settlement, Irkutsk District, 664038, Irkutsk Oblast, Russian Federation; e-mail: vinokurovsi@mail.ru.

\section{Библиографическое описание статьи}

Тяпкина М. Ф. Комбинация стратегического и стейкхолдерского подходов к развитию интегрировано-диверсифицированной компании пищевой промышленности / М. Ф. Тяпкина, С. И. Винокуров // Baikal Research Journal. — 2016. — T. 7, № 2. — DOI : 10.17150/2411$\underline{6262.2016 .7(2) .11 .}$

\section{Reference to article}

Tyapkina M. F., Vinokurov S. I. Combination of strategic and stakeholders' approaches to developing integrated diversified companies in food industry. Baikal Research Journal, 2016, vol. 7, no. 2. DOI: 10.17150/2411-6262.2016.7(2).11. (In Russian).

\section{Baikal Research Journal}

